\title{
OlD SEELAND, NEW NETHERLAND AND NEW ZEALAND: SOME THOUGHTS ON THE POSSIBLE "DISCOVERY" OF INVESTMENT TREATY ARBITRATION IN NEW ZEALAND
}

\author{
Lucy Reed and Robert Kirkness*
}

\begin{abstract}
New Zealand has to date enjoyed the luxury of engaging with the modern investment treaty regime through only three free-trade agreements with compulsory investor-State arbitration clauses. This may be about to change. New Zealand is negotiating a series of further free-trade agreements, including the Trans-Pacific Partnership Agreement, many of which are likely to provide for investor-State dispute resolution. New Zealand faces a choice in these negotiations: should it reject investment treaty arbitration on the basis that the risks, especially the perceived risks of restricted freedom to regulate, are too great or instead seek to make use of the opportunities investment treaty arbitration presents? This article looks at the evolving system of investment treaty arbitration and the different ways in which States seek to make use of it, with a focus on the Netherlands, the United States, and New Zealand.
\end{abstract}

* Partner, Freshfields Bruckhaus Deringer; Associate, Freshfields Bruckhaus Deringer. We would like to thank our colleagues Baxter Roberts and Charlène Valdez-Warner for their assistance with the research for this article. This article is based on the inaugural New Zealand Law Foundation International Dispute Resolution Lecture, entitled "Zealand Old and New: International Arbitration and Trade", delivered by Lucy Reed at Victoria University of Wellington on 7 November 2012. Thanks are due to so many who supported and attended the Lecture, and especially to the New Zealand Law Foundation, the Victoria University of Wellington and University of Auckland Law Faculties, the Arbitrators' and Mediators' Institute of New Zealand [AMINZ], Associate Professor Dr Petra Butler, Deborah Hart, Professor Susy Frankel, and Dr Caroline Foster. 


\section{INTRODUCTION}

The conceit in the title draws on the historical link between New Zealand and the Netherlands. It was the Dutchman Abel Tasman who "discovered" New Zealand and an anonymous cartographer at the Dutch East India Company who was responsible for naming it: ${ }^{1}$

Tasman called the new country Staten Land, because he speculated that it might be the western extremity of the Staten Land off the south-west coast of South America ... When late in 1643 this was perceived to be an impossibility ... an anonymous cartographer in the Dutch East India Company renamed Tasman's line of coast "Nieuw Zeeland" or, in Latin, "Zelandia Nova." ... By the late eighteenth century this scratch of coastline would be identified variously as New Zeeland, New Zeland and, eventually, New Zealand.

Tasman's instructions from the Dutch East India Company, which financed his expedition, reveal one of our central themes: international economic relations, including trade and investment, involve both risk and opportunity. As Michael King explains: ${ }^{2}$

... Tasman's primary responsibility was not cartographical. It was to seek opportunities for gold and silver, spices and fabric. And if the expedition discovered precious metals and minerals, Tasman was to represent himself "not to be too eager for [them] in order to keep the wild savages unaware of the value of the same".

The more functional relevance of the Netherlands for our purposes is that it is an example of a State that embraces investment treaty arbitration. Since the early 1960s, the Netherlands has signed nearly 100 investment treaties, of which over 90 are in force. ${ }^{3}$

We temper this approach by offering a United States perspective. One of the authors is, after all, a New Yorker. Like New Zealand, New York - and by extension the United States - owes a historical debt to the Netherlands: ${ }^{4}$

It was founded by the Dutch, who called it New Netherland, but half its residents were from elsewhere.

Its capital was a tiny collection of rough buildings perched on the edge of a limitless wilderness, but its muddy lanes and waterfront were prowled by a Babel of peoples - Norwegians, Germans, Italians, Jews, Africans (slaves and free), Walloons, Bohemians, Munsees, Montauks, Mohawks, and many others - all living on the rim of empire, struggling to find a way of being together, searching for a balance between

1 Michael King The Penguin History of New Zealand (Penguin Books, New Zealand, 2003) at 99-100.

2 Ibid, at 94 .

3 See International Centre for Settlement of Investment Disputes [ICSID] "ICSID Database of Bilateral Investment Treaties" <https://icsid.worldbank.org/ICSID> and the United Nations Conference on Trade and Development [UNCTAD] Database of Bilateral Investment Treaties at UNCTAD "Investment Instruments Online: Bilateral Investment Treaties" (12 December 2012) <www.unctadxi.org/templates>.

4 Russell Shorto The Island at the Center of the World (Vintage Books, New York, 2005) at 2 and 6. 
chaos and order, liberty and oppression. Pirates, prostitutes, smugglers and business sharks held sway in it. It was Manhattan, in other words, right from the start: a place unlike any other either in the North American colonies or anywhere else.

$\cdots$

It has long been recognized that the Dutch Republic in the 1600s was the most progressive and culturally diverse society in Europe. ... The Netherlands of this time was the melting pot of Europe. The Dutch Republic's policy of tolerance made it a haven for everyone from Descartes to John Locke to exiled English royalty to peasants from across Europe. When this society founded a colony based on Manhattan Island, that colony had the same features of tolerance, openness, and free trade that existed in the home country. Those features helped make New York unique, and in time, influenced America in some elemental ways.

The United States is party to nearly 50 different investment treaties, including the North American Free Trade Agreement (NAFTA) ${ }^{5}$ However, the United States has revised its approach to investment treaties over time in an attempt to ensure that its investment treaties strike a balance between its ability to regulate freely in the public interest domestically and the protections it offers to foreign investors. This "balanced" approach provides a foil for the more expansive approach adopted by the Netherlands.

The United States can also be expected to play a central role in the current Trans-Pacific Partnership (TPP) negotiations. These negotiations aim to create a massive free-trade zone covering the Asia-Pacific region. The States currently involved in negotiations are New Zealand, Australia, Brunei, Chile, Malaysia, Peru, Singapore, Vietnam, Canada, Mexico, and the United States. ${ }^{6}$ Japan and Thailand may soon join. ${ }^{7}$ An agreement between these States would redefine the international legal framework governing trade and investment in the Asia-Pacific region. It would also have a number of implications for the domestic legal systems of those States, including New Zealand.

New Zealand is currently party to only three international instruments that provide for binding investor-State dispute resolution. ${ }^{8}$ It has never been sued by a foreign investor. And no New

5 See the legal text of the North American Free Trade Agreement 32 ILM 289 (opened for signature 17 December 1992, entered into force 1 January 1994).

6 New Zealand Ministry of Foreign Affairs and Trade [MFAT] "Trans-Pacific Partnership (TPP) Negotiations" (24 February 2012) <www.mfat.govt.nz>.

7 See Yoshihiko Noda, former Prime Minister of Japan "Press Conference by Prime Minister Yoshihiko Noda on the Occasion of the 19th APEC Economic Leaders' Meeting" (13 November 2012) Prime Minister of Japan and His Cabinet <www.kantei.go.jp>; and Yingluck Shinawatra, Prime Minister of Thailand "Joint Press Conference by Prime Minister Yingluck Shinawatra of Thailand and President Barack Obama of the United States" (18 November 2012) Royal Thai Government <www.thaigov.go.th>.

8 New Zealand only has three treaties in force that offer the option of investment treaty arbitration: Agreement establishing the ASEAN-Australia-New Zealand Free Trade Area [2006] NZTS 6 (signed 27 
Zealand investors are known to have initiated arbitration proceedings against other States. This will change - and change suddenly - if any TPP agreement provides for compulsory investor-State dispute resolution. New Zealand investors will enjoy enforceable standards of protection in a number of key overseas markets; at the same time, New Zealand will be exposed to potential claims by aggrieved investors from some of the world's largest economies, including - depending on planning and policy - in the domestic, regulatory space. The TPP negotiations are thus likely to present New Zealand with a choice about how to approach investment treaty arbitration.

This is a choice that should not be made lightly. It also requires an appreciation of history and context - to which we turn.

\section{INVESTMENT TREATY ARBITRATION: AN OVERVIEW}

Treaty-based protections for foreign investment have developed in response to the inadequacies of the international legal framework.

In the absence of agreement by the host State to arbitrate disputes directly with foreign investors, an aggrieved foreign investor has inauspicious options. One solution is for the investor to negotiate directly with the host State to get some form of redress. There is little doubt that achieving a solution through negotiation is desirable and may even preserve the relationship between the investor and the host State. Sadly, a negotiated solution is often impossible. A host State's conduct may be motivated by domestic political considerations that are inconsistent with the particular investment project or the host State may take a hostile view of foreign investment and investors.

If no negotiated solution is possible, the foreign investor can theoretically seek a remedy in the host State's courts. The attractiveness of this option will depend on the impartiality, efficiency, and commercial competence of those courts, and the host State's ability to claim sovereign immunity. Traditionally, foreign investment flows went from capital exporting States to capital importing States. The domestic courts of those countries often did not offer a satisfactory option for resolving disputes between foreign investors and the host State. Even when developed economies with well-

February 2009, entered into force 1 January 2010), ch 11 at s B [ASEAN-Australia-New Zealand FTA]; New Zealand-Malaysia Free Trade Agreement [2010] NZTS 9 (signed 26 October 2009, entered into force 1 August 2010), ch 10 at s B [New Zealand-Malaysia FTA]; Free Trade Agreement between the Government of New Zealand and the Government of the People's Republic of China [2008] NZTS 19 (signed 7 April 2008, entered into force 1 October 2008), ch 11 at s 2 [China-New Zealand FTA].

9 It is not possible to do more than sketch some of the key features of investment treaty arbitration in an article of this length. Interested readers are referred to the following general texts by way of introduction to this area: Rudolf Dolzer and Christoph Schreuer Principles of International Investment Law (2nd ed, Oxford University Press, New York, 2012); Campbell McLachlan, Laurence Shore and Matthew Weiniger International Investment Arbitration: Substantive Principles (Oxford University Press, New York, 2007); and Andrew Newcombe and Lluís Paradell Law and Practice of Investment Treaties: Standards of Treatment (Kluwer Law International, The Netherlands, 2009). 
regarded court systems are involved, many investors are reluctant to rely on the courts of the State they are trying to sue for a remedy.

The only other option is for the foreign investor to ask its home State to take action on its behalf. One method used by North American and European powers at the beginning of the 20th century was so-called "gunboat diplomacy". The phrase itself is something of an oxymoron today, but it is a faithful historical description. A good example is the naval blockade imposed by Germany, the United Kingdom and Italy on Venezuela, because of Venezuela's refusal to compensate their nationals for damage to their property during the Venezuelan Civil War. ${ }^{10}$ We can only hope that this kind of "might is right" action stays consigned to history.

A more civilised home State response is to espouse the investor's claim before an international tribunal. This too has its problems. First, some States required foreign investors to waive the benefits of diplomatic protection as a condition of entry. Second, under customary international law, espousal is usually only possible if the investor has exhausted all available domestic law remedies. Third, the home State may have political and economic interests trumping espousal for a single investor. Even in the event of espousal, the investor will not have control over the proceedings and will have no guarantee of payment if its home State is successful. This has more to do with the historical development of international law as a State-centric system than any principled reason why an investor should rely on a third party to bring proceedings on its behalf.

\section{A ICSID Arbitration}

The concern with State-to-State resolution of foreign investment disputes is that it politicises the dispute resolution process. The 1965 Convention on the Settlement of Investment Disputes between States and Nationals of Other States (ICSID Convention) was motivated by a desire to depoliticise foreign investment disputes. ${ }^{11}$ There are currently nearly 150 State parties to the ICSID Convention. ${ }^{12}$

The ICSID Convention created a bespoke World Bank forum and legal framework for the resolution of investment disputes between State parties and nationals of those States. It also

10 For further examples of "gunboat diplomacy", see Christopher Dugan and others Investor-State Arbitration (Oxford University Press, United States, 2008) at 26-27.

11 Convention on the Settlement of Investment Disputes between States and Nationals of other States 575 UNTS 159 (opened for signature 18 March 1965, entered into force on 14 October 1966) [ICSID Convention]. New Zealand signed the ICSID Convention on 2 September 1970. The ICSID Convention entered into force for New Zealand on 2 May 1980. On the depoliticising role envisaged for ICSID, see Ibrahim FI Shihata "Towards a Greater Depoliticization of Investment Disputes: The Roles of ICSID and MIGA" (1986) 1 ICSID Review 1.

12 As of 25 July 2012, 147 States had signed and ratified the Convention: see ICSID "List of Contracting States and Other Signatories of the Convention" (25 July 2012) <https://icsid.worldbank.org/ICSID>. 
established the International Centre for the Settlement of Investment Disputes (Centre) to administer those disputes. ${ }^{13}$

The Centre's jurisdiction is limited to "any legal dispute arising out of an investment between a Contracting State ... and a national of another Contracting State" where the parties have given "consent in writing" to the Centre. There are three ways in which consent can be given: (i) in an investor-State contract; ${ }^{14}$ (ii) in a standing offer in domestic legislation; ${ }^{15}$ or (iii) in a standing offer in a treaty.

The Centre publishes rules of procedure governing the institution and conduct of proceedings, including what is required in a request for arbitration, and the process and timeframes to be followed for each step of the arbitration. ${ }^{16}$ Once the Centre registers a request, it is no longer possible to withdraw unilaterally from the arbitration proceedings. ${ }^{17}$ The only options are to settle or to see the process through to an award.

The ICSID system is self-contained and rigorous. Contracting States are required to recognise awards and enforce pecuniary obligations imposed under those awards as if they were final judgments of their own courts. ${ }^{18}$

There is no right to appeal an award under the ICSID Convention to any court. ${ }^{19}$ Instead, a party may in limited circumstances seek to annul the tribunal's award. ${ }^{20}$ Once an annulment request has

13 Article 1.

14 See, for an example of this type of contractual dispute resolution clause, Mobil Oil Corp, Mobil Petroleum Co Inc and Mobil Oil New Zealand Ltd $v$ The Queen (Findings on Liability, Interpretation, and Allied Issues) (1989) 4 ICSID Reports 140.

15 See for example the provision at issue in SPP $v$ Egypt which provided that:

Investment disputes in respect of the implementation of the provisions of this Law shall be settled ... within the framework of the [ICSID Convention] to which Egypt has adhered by virtue of Law No. 90 of 1971, where it applies.

The tribunal found that it had jurisdiction to hear the claim on the basis of this provision: Southern Pacific Properties (Middle East) Ltd v Egypt (Jurisdiction) ICSID ARB/84/3, 14 April 1988 at [22] [SPP v Egypt].

16 The ICSID Rules of Procedure for the Institution of Conciliation and Arbitration Proceedings [ICSID Institution Rules] and ICSID Rules of Procedure for Arbitration Proceedings [ICSID Arbitration Rules] are available online at ICSID <https://icsid.worldbank.org/ICSID>.

17 ICSID Institution Rules, ibid, at r 8.

18 If recognition and enforcement are sought in a State that is not a party to the ICSID Convention, the standard rules governing enforcement of foreign arbitral awards set out in the New York Convention apply: Convention on the Recognition and Enforcement of Foreign Arbitral Awards 330 UNTS 3 (opened for signature 10 June 1958, entered into force 7 June 1959) [New York Convention]. The New York Convention also applies to enforcement of non-pecuniary awards.

19 Article 53. 
been made, the Secretary-General will appoint an ad hoc committee of three arbitrators, who have the authority to annul the award if the requesting party can bring itself within one of the limited grounds set out in art 52(1) of the ICSID Convention. The grounds are that: (i) the tribunal was not properly constituted; (ii) it has "manifestly exceeded its powers"; (iii) it was corrupt; (iv) there was a "serious departure from a fundamental rule of procedure"; or (v) there has been a failure to give the reasons on which the award was based. This list is exhaustive.

The success of the ICSID Convention and the Centre is seen in the central role that the Centre plays in modern investment treaty arbitration and in particular the fact that it administers the majority of investor-State arbitrations. ${ }^{21}$

\section{B Modern Investment Treaties}

Treaty-based investment protections are found in bilateral investment treaties (BITs), multilateral investment treaties, or investment chapters embedded in free-trade agreements (FTAs). ${ }^{22}$

As treaties, these are instruments of international law subject to the rules governing the interpretation of treaties in the 1969 Vienna Convention on the Law of Treaties. ${ }^{23}$ The importance of international law is explicitly addressed in the ICSID Convention, which provides that the applicable law of an ICSID Convention dispute is the law agreed between the parties or, if there is no agreement, "the law of the Contracting State party to the dispute (including its rules on the conflict of laws) and such rules of international law as may be applicable." 24 In practice, international law governs treaty disputes.

Most modern investment treaties share the same basic structure and content. This applies irrespective of the geography and cultural history of the contracting States, and irrespective of whether the investment protections are in a BIT, multilateral investment treaty or FTA. Negotiating treaty-based investment protections with China is different from negotiating a treaty with India, which in turn is different from negotiating with the United States, but the final product is likely to look very similar.

20 Article 52.

21 UNCTAD "Latest Developments in Investor-State Dispute Settlement" (April 2012) <http://unctad.org/en> at 1: "The majority of investment cases continues to accrue under ICSID (or under ICSID Additional Facility) (in total now 279 cases) and the United Nations Commission on International Trade Law [UNCITRAL] (126)".

22 One notable exception is the sector-specific Energy Charter Treaty 2080 UNTS 95 (opened for signature 17 December 1994, entered into force 16 April 1998) which includes investment protections.

23 Vienna Convention on the Law of Treaties 1155 UNTS 331 (opened for signature 23 May 1969, entered into force 27 January 1980)

24 Article 42(1). 


\section{The Scope of the Treaty}

The door opener to an investment treaty is the definitions of "national" and "investment". The nationality of corporations for the purposes of a treaty is generally determined by the place of incorporation. In some BITs, formal incorporation is all that is required; other BITs require a substantive economic relationship between the corporation and the home State, that is headquarters based in that State or concrete business activity. ${ }^{25}$

The definition of "investment" determines the subject matter jurisdiction of the tribunal. Investment is often defined in broad terms like "every asset that an investor owns or controls, directly or indirectly", followed by a non-exhaustive list of examples like real property, shares, and intellectual property rights. ${ }^{26}$ The basic characteristics of an investment compared with a simple contract are said to be: (i) a certain duration; (ii) a certain regularity of profit and return; (iii) assumption of risk; and (iv) significance for the host State's development. ${ }^{27}$ As several tribunals have found, "investment" is a broader economic concept covering the different interrelated aspects of the investment process. ${ }^{28}$

\section{Investor Protection Standards}

The substantive investor protection standards in investment treaties are broadly similar although the precise wording varies from treaty to treaty. Given the purpose of treaties, the language focuses on protecting foreign investment rather than on defending countervailing State concerns.

25 See Treaty Between the Government of the United States of America and the Government of [Country] Concerning the Encouragement and Reciprocal Protection of Investment [2012 United States Model bilateral investment treaty [BIT]] (available online at the Office of the United States Trade Representative <www.ustr.gov>). Article 1 defines an "enterprise of a Party" as "an enterprise constituted or organized under the law of a Party". The IBO Modelovereenkomst [2004 Dutch Model BIT] (available online at International Ondernemen of the Central Government (Rijksoverheid) (2004) <www.rijksoverheid.nl>), art 1(b)(ii) defines "nationals" as "legal persons constituted under the law of that Contracting Party".

26 See, for example, 2012 United States Model BIT, ibid, at art 1. See also Agreement between the Government of Australia and the Government of the United Mexican States on the Promotion and Reciprocal Protection of Investments, and Protocol [2005] ATNIF 16 (signed 23 August 2005, entered into force 21 July 2007), art 1(a).

27 Christoph Schreuer The ICSID Convention: A Commentary (2nd ed, Cambridge University Press, New York, 2009) at [153], citing Fedax NV v Venezuela (Jurisdiction) ICSID ARB/96/3, 11 July 1997 at [22][23]. See also, more generally on the "restrictive approach", Julian Davis Mortenson "The Meaning of 'Investment': ICSID's Travaux and the Domain of International Investment Law" (2010) 51 Harv Intl L J 257 at 271-276; and on the general characteristics of an investment, Noah Rubins "The Notion of 'Investment' in International Investment Arbitration" in Norbert Horn and Stefan Michael Kröll (eds) Arbitrating Foreign Investment Disputes: Procedural and Substantive Legal Aspects (Kluwer Law International, The Netherlands, 2004) 283 at 297-300.

28 See Biwater Gauff v Tanzania (Award) ICSID ARB/05/22, 24 July 2008 at [316]. For a more general discussion on the definition of "investment", see Dolzer and Schreuer, above n 9, at 66-76. 
The core list of these treaty standards includes: (i) national treatment; (ii) most favoured nation (MFN) treatment; (iii) fair and equitable treatment (FET); (iv) full protection and security; and (v) protection against expropriation without full compensation.

The first two standards are relative ones. National treatment is meant to protect a foreign investor from treatment less favourable than that received by host State nationals. MFN treatment is meant to protect a foreign investor from treatment less favourable than that received by third State investors.

In comparison, the FET and full protection and security standards set baselines below which a host State's conduct is not to fall. The FET standard is one of the most commonly pleaded - and most elusive - standards in investment treaty arbitration. A key challenge facing arbitral tribunals is how to develop an analytical framework within which to apply this standard. Professor Campbell McLachlan QC explains the way in which the standard captures a broad range of principles: ${ }^{29}$

... the general principles informing the standard flow from its character as an instrument of supervision

at the international law level of the processes of governmental decision-making at national level. The

standard is concerned with due process in decision-making, and not with substantive outcomes. It

requires the application of fundamental rule-of-law values in decision-making: predictability;

accessibility; impartiality; and natural justice, as contrasted with arbitrary action.

We would add only that, in our view, the supervision to which Professor McLachlan refers extends beyond the formal process of governmental decision-making to include representations made by a host State to a foreign investor. If a host State creates legitimate expectations in a foreign investor, it should fairly be held to them.

The full protection and security standard is principally concerned with the host State's exercise of its police power. It imposes a positive obligation on host States to protect an investment from the actions or inaction (failure to protect) of State officials.

Another key protection in investment treaties is the prohibition against unlawful expropriation. Treaties usually provide that a State can lawfully expropriate foreign investors' investments only if the taking is: (i) for a public purpose; (ii) not arbitrary or discriminatory; and (iii) accompanied by full compensation. Historic expropriations of investments have largely (but not wholly) been replaced by more subtle regulatory expropriations - opening up policy arguments about how to draw the line between indirect or creeping expropriation and legitimate regulation in the public interest.

29 Campbell McLachlan "Investment Treaties and General International Law" (2008) 57 International and Comparative Law Quarterly 361 at 400. 


\section{E "Arbitration Without Privity"}

The real muscle of modern investment treaties is the right of foreign investors to sue host States directly before an international arbitration tribunal for breach of the substantive protection standards in those treaties.

Most modern investment treaties include dispute resolution clauses in which States agree to submit disputes with aggrieved investors from the other contracting States to international arbitration. Unless accompanied by an express reservation or qualified in some other way, this will be construed as a standing offer to arbitrate disputes with investors from the other contracting States. ${ }^{30}$

The 2004 Dutch Model BIT offers an example of such a clause: $:^{31}$

Each Contracting Party hereby consents to submit any legal dispute arising between that Contracting

Party and a national of the other Contracting Party concerning an investment of that national in the territory of the former Contracting Party to the International Centre for the Settlement of Investment Disputes for settlement by conciliation or arbitration under the Convention on the Settlement of Investment Disputes between States and Nationals of other States, opened for signature at Washington on 18 March 1965.

To accept this type of offer, an aggrieved investor simply needs to follow the process set out in the clause and any relevant institutional rules - here, ICSID. This represents a significant development in international law because it enables a private entity to sue a State without a contractual arrangement between the investor and the State.

In a prescient 1996 article, our colleague Jan Paulsson coined the phrase "arbitration without privity" to describe this feature of modern investment treaties. Paulsson offered the following insight: ${ }^{32}$

The possibility of direct action - international arbitration without privity - allows the true complainant to face the true defendant. This has the immense merit of clarity and realism; these virtues, and not eloquent proclamations, are the prerequisites of confidence in the legal process.

\section{F An Evolving System}

Initial uptake of the ICSID arbitration avenue was slow. The first known investor-State arbitration was initiated by Asian Agricultural Products Ltd (AAPL) against the Government of Sri

30 Christoph Schreuer "The Dynamic Evolution of the ICSID System" in Rainer Hofmann and Christian J Tams (eds) The International Convention on the Settlement of Investment Disputes (ICSID):Taking Stock after 40 Years (Nomos Publishers, Baden-Baden, 2007) 15 at 18.

31 Article 9.

32 Jan Paulsson "Arbitration Without Privity" (1995) 10 ICSID Foreign Investment Law Journal 232 at 256. 
Lanka for the destruction of a shrimp farm by Government forces in 1987. Sri Lanka did not challenge jurisdiction and the tribunal found that AAPL was entitled to initiate ICSID arbitration on the basis of Sri Lanka's unilateral offer to submit disputes to arbitration in art 8(1) of the United Kingdom-Sri Lanka BIT. ${ }^{33}$ In 1990, the tribunal awarded compensation to AAPL.

If investment treaty arbitrations were slow to take off, the last 20 years have seen an explosion in both the number of treaties and the number of disputes going to arbitration. The United Nations Conference on Trade and Development reported in April 2012 that at least 46 cases were filed in 2011 alone - the highest number of investment treaty arbitrations filed in a single year. ${ }^{34}$ This brought the total number of known disputes to 450, of which around 220 have been concluded. Since many disputes are confidential, the number of disputes may in fact be higher.

This explosion in investor-State arbitration has had three principal effects. First, investors are increasingly aware of the benefits of treaty protections. Sophisticated investors now seek to reduce risk to their global investment portfolios by structuring their investments to benefit from treaty protections.

Second, and as a result, this has changed the risk calculus for States when signing up to these treaties. States must now take more account of the very real possibility that they will be lobbied or sued by aggrieved foreign investors in the wake of host State actions or policies. Further, the traditional capital exporting/capital importing dichotomy is breaking down and an increasing number of BITs are being entered into between developed economies. This means the likelihood that traditional capital exporting countries will face treaty arbitration is steadily increasing. This is particularly true in the case of multilateral FTAs which often involve two or more developed economies.

Third, the various arbitrations and awards have road-tested the legal frameworks for investment arbitration established in these treaties. Many were entered into before there was a body of investment treaty "jurisprudence" to inform the drafting process. States now have the benefit of some 220 known cases and a vast (and ever expanding!) academic literature to guide future treaty amendment and drafting efforts.

This has led many States to reassess their approach to the content of investment treaties. Many now explicitly address the relationship between the protections offered to foreign investors and their responsibility to regulate in the public interest, particularly in areas like national security, environmental protection and human rights. In the absence of explicit textual support, tribunals have also drawn on other areas of international law - such as international trade law and international

33 Asian Agricultural Products Ltd v Sri Lanka (Final Award) ICSID ARB/87/3, 27 June 1990. In 1985, an ICSID tribunal had found jurisdiction in the SPP $v$ Egypt dispute on the basis of a provision in the Egyptian foreign investment law: see SPP $v$ Egypt, above n 15.

34 UNCTAD, above n 21, at 1 . 
human rights law - to interpret investment treaties to balance the tension between investor protection and countervailing State interests. The different State responses to investment treaty arbitration are considered next.

\section{STATE RESPONSES TO INVESTMENT TREATY ARBITRATION}

\section{A An "Open Door" Policy}

Some States have done little to adapt their existing treaties. A good example is the Netherlands, which seeks to attract foreign investors by offering access to its network of double taxation and investment treaties. The Netherlands concluded its first BIT in $1963^{35}$ and had signed just under 100 BITs by $2010 .{ }^{36}$

The 2004 Dutch Model BIT maintains an open door policy by offering arbitration (see the provision above at Part II B 3), broadly defining "investment" and perhaps most importantly defining "national" as it applies to corporations to require only that the company be incorporated in accordance with the laws of the Netherlands. Absent a requirement for a substantive economic connection between the Netherlands and the relevant company, so-called "shell" Dutch companies can seek the protection of Dutch treaties. In Saluka v Czech Republic, ${ }^{37}$ for example, Saluka Investments BV was a Dutch subsidiary incorporated in the Netherlands by the Nomura Group for the purposes of investing in the Czech Republic banking sector. The Czech Republic raised a jurisdictional challenge against Saluka's ability to claim Dutch nationality for the purposes of the treaty. The tribunal rejected the challenge on the basis that this issue was to be determined in accordance with the text of the treaty and the text was clear that nothing more than Dutch incorporation was required.

Further, the substantive investment protection standards in the 2004 Dutch Model BIT are broadly framed, with environmental and labour considerations relegated to the Preamble. Although this style of investment treaty has been criticised for failing to take into account countervailing State interests, such as human rights and environmental concerns, criticisms can be overblown. This treaty structure is not a blank cheque to compensate foreign investors for any and all impact on profits caused by legitimate regulation. There is much room in international law to balance these tensions, and a proper role for arbitrators, counsel, and academics in the process. An "open door" in treaties like those of the Netherlands is not a one-way door.

35 See Roos van Ors and Roeline Knottnerus Dutch Bilateral Investment Treaties: a gateway to 'treaty shopping' for investment protection by multinational companies (SOMO, Amsterdam, 2011) at 16.

36 Ibid.

37 Saluka v Czech Republic (Partial Award) (2006) 15 ICSID Reports 274. 


\section{B The Malcontents}

In contrast, several countries have flat-out rejected investment treaty arbitration. This group includes Argentina, Bolivia, Ecuador, Nicaragua, and Venezuela. This is not surprising given their unprecedented track record at ICSID - these five States have faced being respondents in 109 of the 450 claims brought under the ICSID Convention. ${ }^{38}$

Venezuela became the third country to withdraw from the ICSID Convention in January 2012, following Bolivia in 2007 and Ecuador in 2010. ${ }^{39}$ A press release by the Venezuelan Ministry of Foreign Affairs blames the perceived ideological bias of the ICSID system as one of its reasons for withdrawal. Venezuela claims that ICSID tribunals have "ruled 232 times in favour of transnational interests out of the 234 cases filed throughout its history". ${ }^{40}$ In fact, the ICSID statistics show that States are more often successful than investors. ${ }^{41}$

Australia is a surprising recent addition to the malcontents. Australia is not withdrawing from its existing treaty obligations but it has publicly taken the position that it will no longer enter into treaties providing for investor-State arbitration. ${ }^{42}$

This must be seen against the backdrop of the treaty arbitration brought by Philip Morris over proposed "plain packaging" legislation for tobacco products. Philip Morris' claim is that the "plain packaging" legislation breaches its rights to be treated fairly and equitably and amounts to expropriation of its intellectual property rights in branding. ${ }^{43}$ The Philip Morris tribunal will

38 See UNCTAD, above n 21, at Annex 2.

39 Bolivia filed its notification of withdrawal under art 71 of the ICSID Convention on 2 May 2007; Ecuador's notification was filed on 7 January 2010; and Venezuela's notification was filed on 24 January 2012. News releases of all three denunciations are available online at ICSID < https://icsid.worldbank.org/ICSID>. See also, more generally, Andrés A Mezgravis and Carolina González "Denunciation of the ICSID Convention: Two Problems, One Seen and One Overlooked" (2012) 9 TDM 1.

40 This is a free translation of a press release by the Government of Venezuela "Gobierno Bolivariano denuncia convenio con CIADI" (25 January 2012) Venezuelan Ministry of Foreign Affairs <www.mre.gov.ve>.

41 As of 30 June 2012, ICSID's statistics indicate that only 48 per cent of claims in which a tribunal has delivered a final award on the merits have resulted in the investor's claim being upheld in part or in full: see ICSID "ICSID Caseload Statistics: Issue 2012-2" (30 June 2012) <https://icsid.worldbank.org/ICSID> at 13.

42 Government of Australia "Gillard Government Trade Policy Statement: Trading our way to more jobs and prosperity" (April 2011) Australian Department of Foreign Affairs and Trade <www.dfat.gov.au> at 14 This was based on the recommendations of the Australian Productivity Commission in its report Bilateral and Regional Trade Agreements (13 December 2010) (available online at <www.pc.gov.au/projects/study/trade-agreements/report>).

43 Letter from Allens Arthur Robinson (Lawyers for Philip Morris Asia Ltd) to the Hon Robert McClelland MP (Attorney-General for Australia) regarding Philip Morris Asia Ltd's Notice of Claim Under the Australia/Hong Kong Agreement for the Promotion and Protection of Investments (15 July 2011) (available 
consider whether these alleged treaty rights, if proven, trump Australia's ability to regulate for public health purposes, under international law. The decision is in the future. We note only that it is a very different thing for a State to be sued, and defend itself, than to lose and face an award.

Australian investors face the consequences of their Government's new policy. The recent 2011 decision in White Industries Australia Ltd v India is a good example of the benefits of investment protection to Australian investors. ${ }^{44}$ White Industries, an Australian company, had been seeking to enforce a commercial arbitral award against an Indian construction company for almost a decade, but had been unable to do so due to various impediments in the Indian court system. White Industries initiated arbitration against the Government of India under the India-Australia BIT, and successfully argued that the MFN clause granted it the protection of a more favourable provision in the India-Kuwait BIT, which required the States to provide foreign investors with an "effective means of asserting claims". ${ }^{45}$ The tribunal concluded that India had denied White Industries an "effective means" to enforce its rights, and ordered India to pay the amount of the commercial arbitration award to White Industries. If Australia's new policy had been in place, White Industries would still be unpaid.

Australia's rejection of investor-State arbitration in future treaties means that the inclusion of compulsory investor-State arbitration is certain to be one topic of debate in the TPP negotiations. ${ }^{46}$ If an investor-State arbitration provision is included in the final text of the TPP, Australia is likely to seek to protect its position by negotiating a carve-out such as the one entered into with New Zealand over the investment chapter to the ASEAN-Australia-New Zealand FTA. ${ }^{47}$

\section{The "Balanced" Approach}

A number of States are taking a middle-of-the-road approach to treaty arbitration. These States have existing BIT programmes but are reviewing their approach to negotiating new treaties in light

online at Australian Department of Foreign Affairs and Trade <http://dfat.gov.au/foi/downloads/dfat-foi-1120550.pdf>).

44 White Industries Australia Ltd v India (Final Award) UNCITRAL, 30 November 2011. We note that Planet Mining Pty Ltd, an Australian-based mining company, has just registered a claim with ICSID against Indonesia: see Planet Mining Pty Ltd v Indonesia ICSID ARB/12/40.

45 Agreement between the Republic of India and the State of Kuwait for the Encouragement and Reciprocal Protection of Investments (signed 27 November 2001, entered into force 28 June 2003), art 4(5). See also the tribunal's decision on this point: White Industries Australia Ltd v India, ibid, at [11.2.1]-[11.2.9].

46 Australian Productivity Commission, above n 42, at 275-276.

47 See Letter from Hon Tim Groser (New Zealand Minister of Trade) to Hon Simon Crean (Australian Minister for Trade) regarding the ASEAN-Australia-New Zealand Free Trade Area negotiations (27 February 2009) (available online at <www.aseanfta.govt.nz>). 
of lessons learned in the last 20 years. ${ }^{48}$ A leading example is the United States, which revised its Model BIT in 2004 and again in 2012.

The United States Model BIT contains a number of innovative drafting developments designed to improve the substance and process of investment treaties entered into by the United States. Although it contains broad definitions of "investor" and "investment", the treaty also contains a strong denial of benefits clause allowing the host State to deny the benefits of the treaty to parties without substantial business activities in the home State. ${ }^{49}$

The United States Model BIT contains broad protections for foreign investors in its national treatment and MFN standards that extend to the "establishment" and "acquisition" of both investors and investments. ${ }^{50}$ The FET and full protection and security standards expressly do not require treatment above the (bare) minimum standard of treatment under customary international law. ${ }^{51}$

The expropriation standard is to be interpreted in light of an expropriation annex that more clearly distinguishes between direct and indirect expropriation. ${ }^{52}$ It also expressly provides that nondiscriminatory regulatory actions by a party to protect legitimate public welfare objectives will rarely be considered an indirect expropriation..$^{53}$

The United States Model BIT includes specific provisions dealing with environmental concerns and labour rights. The environmental provision explicitly recognises the rights of parties to exercise discretion with respect to regulatory, compliance, and investigatory matters. ${ }^{54}$ It also recognises that environmental laws should not be weakened or reduced to encourage investment. ${ }^{55}$ Environmental laws are defined broadly to include statutes or regulations with the primary purpose of protecting the environment or preventing danger to human, animal or plant life or health. ${ }^{56} \mathrm{~A}$ similar provision

48 Republic of South Africa Bilateral Investment Treaty Policy Framework Review (Department of Trade and Industry, Executive Summary of Government Position, June 2009) at 5. See also on this topic Dr Rob Davies, Minister of Trade and Industry of the Republic of South Africa "Speaking notes at the Discussion of UNCTAD's Investment Policy Framework for Sustainable Development" (UNCTAD's 59th Trade and Development Board Meeting, Geneva, 24 September 2012).

49 Article 17(2).

50 Articles 3 and 4

51 Article 5.

52 Annex B.

53 Annex B (4)(b).

54 Article 12

55 Article 13.

56 Article 12 
applies in respect of domestic labour laws. ${ }^{57}$ There is also a specific carve-out for measures that a party considers necessary to fulfil its obligations for maintaining and restoring international peace and security or protection of its own essential security interests. ${ }^{58}$

The United States Model BIT contains a number of procedural innovations. If a host State claims that a measure alleged to be a breach is within the scope of a specific exception, the host State can request and the tribunal must ask for an interpretation of the relevant provision by the parties. A joint decision by the contracting States on the issues will be binding on the tribunal.

The United States Model BIT also requires greater transparency in investor-State arbitration. All the key documents submitted to a host State must be made available to the public ${ }^{59}$ and the tribunal's hearings must be conducted in public. ${ }^{60}$ The other contracting States are entitled to make oral and written submissions on the interpretation of the treaty, ${ }^{61}$ and the tribunal is able to invite amicus curiae submissions from third parties. ${ }^{62}$

\section{NEW ZEALAND'S TREATY PRACTICE}

\section{A New Zealand's Existing Exposure to Investment Treaty Arbitration}

New Zealand is currently party to three FTAs that provide for compulsory investor-State dispute resolution: the 2008 China-New Zealand FTA, the 2009 ASEAN-Australia-New Zealand FTA, and the 2009 Malaysia-New Zealand FTA, which builds on the trade and investment provisions Malaysia and New Zealand agreed to as part of the broader negotiations with Australia and the other ASEAN nations (Brunei, Myanmar, Singapore, the Philippines and Vietnam).

New Zealand's investment chapters in these three FTAs reflect the "balanced" approach to investment treaty arbitration described above. Each of the investment chapters in these FTAs preserves regulatory space for the New Zealand Government in areas of national interest. This is reflected in several provisions.

The national treatment provisions apply only post-establishment of an investment, thereby preserving the ability of the New Zealand Government to control the process whereby foreign investments are allowed. ${ }^{63}$ In both the ASEAN-Australia-New Zealand FTA and the Malaysia-

57 Article 13.

58 Article 18. See also arts 17(1) and 29(4).

59 Article 29(1).

60 Article 29(2)

61 Article 28(2).

62 Article 28(3).

63 China-New Zealand FTA, above n 8, at art 138. 
New Zealand FTA, the national treatment obligation does not apply to certain existing measures, sectors, and activities set out in annexes.

The MFN provisions (only in the China-New Zealand and Malaysia-New Zealand FTAs) expressly do not apply to dispute resolution procedures, limiting investors from using the MFN avenue to obtain the benefit of "better" dispute resolution processes under different investment treaties. ${ }^{64}$

The China-New Zealand FTA draws on the approach to expropriation found in the United States Model BIT by requiring that the treaty text must be read together with an expropriation annex that defines in greater detail the precise meaning of both direct and indirect expropriation. ${ }^{65}$ This is intended to limit tribunal findings of direct or creeping expropriation through regulation in the public interest. This same approach is also found in the ASEAN-Australia-New Zealand FTA and the Malaysia-New Zealand FTA. ${ }^{66}$

One significant difference between the three New Zealand FTAs is the FET standard. In the China-New Zealand FTA, this standard is free-standing and not expressly tied to the customary international law minimum standard, allowing an interpretation higher than the customary international law standard requiring egregious or shocking conduct by the State. ${ }^{67}$ In both the ASEAN-Australia-New Zealand FTA and the Malaysia-New Zealand FTA, the link between the FET standard and the customary international law minimum standard is expressly made. ${ }^{68}$

The New Zealand FTAs with China and Malaysia also include extensive general exceptions designed to preserve State flexibility. There are two types of exceptions. First, the New Zealand FTAs with China and Malaysia directly incorporate the two key general exception provisions in international trade law: art XX of the General Agreement on Tariffs and Trade and art XIV of the General Agreement on Trade in Services. These general exceptions are applicable to the entire trade agreements, including their investment chapters, and are intended to allow regulatory space to pursue certain public objectives such as public health and protection of natural resources. ${ }^{69}$ Second,

64 China-New Zealand FTA, above n 8, at art 139; New Zealand-Malaysia FTA, above n 8, at art 10.21(6). But see for more limited incorporation of these provisions the ASEAN-Australia-New Zealand FT A, above n 8 .

65 China-New Zealand FTA, above n 8, at Annex 13.

66 New Zealand-Malaysia FTA, above n 8, at Annex 7; ASEAN-Australia-New Zealand FTA, above n 8, at Annex 13.

67 China-New Zealand FTA, above n 8, at art 154.

68 New Zealand-Malaysia FTA, above n 8, at art 10.10(2)(c); ASEAN-Australia-New Zealand FTA, above n 8 , at art 6(c).

69 China-New Zealand FTA, above n 8, at art 200. See also New Zealand-Malaysia FTA, above n 8, at art 10.21(6). But see for more limited incorporation of these provisions the ASEAN-Australia-New Zealand FTA, above $\mathrm{n} \mathrm{8}$, at art 79. The fact that the ASEAN-Australia-New Zealand FTA does not include 
the China-New Zealand FTA includes a list of specific exceptions including: measures to protect essential security interests; measures to safeguard the balance of payments; measures to preserve the stability of the financial system; taxation measures; measures necessary to fulfil obligations under the Treaty of Waitangi; and specific exceptions for measures to protect New Zealand's artistic and cultural heritage. ${ }^{70}$ The Malaysia-New Zealand FTA contains similar specific exceptions. ${ }^{71}$

\section{B New Zealand's Choice}

The fact that New Zealand has signed so few treaties to date leaves it well-placed to make an informed assessment of the risks and opportunities of investment treaty arbitration unencumbered by an existing treaty practice. Very few developed economies are able to assess the potential strengths and weaknesses of the investment treaty system with such a clean slate and so much information.

The good news is that New Zealand has the choice whether to make greater use of that system, weighing whether its risks outweigh the potential benefits to New Zealand and New Zealand investors. The bad news is that New Zealand is unlikely to have much time for reflection. In addition to bilateral negotiations for FTAs with India, Russia, and Hong Kong, ${ }^{72}$ the TPP negotiations alone include Australia, Brunei, Canada, Chile, Malaysia, Mexico, Peru, Singapore, the United States and Vietnam. ${ }^{73}$ Japan and Thailand may also join the negotiations. ${ }^{74}$ The United States has set a target of the end of 2013 to close the deal. ${ }^{75}$

The proposed TPP will reshape the economic relations between the contracting States, including New Zealand: that is, after all, one of its central objectives. The fact that the investment protections in FTAs like the TPP are embedded within broader trade agreements makes it more difficult to anticipate the outcome. Investment protections need to be agreed by all the negotiating parties but are themselves likely to be subject to trade-offs during negotiations over other measures in the agreement. However, given the general alignment on approach between the 2012 United States

provisions as extensive as those found in New Zealand's FTAs with China and Malaysia may suggest that Brunei, Singapore and Vietnam will be more resistant to their inclusion in any Trans-Pacific Partnership agreement.

70 Articles 200-205

71 Article 10.21(6).

72 See MFAT "Trade Relationships and Agreements" (19 December 2012) <www.mfat.govt.nz>.

73 MFAT, above n 6.

74 See International Centre for Trade and Sustainable Development "Thailand Expresses Interest in Joining Trans-Pacific Trade Talks, as TPP Leaders Set New Deadline" Bridges Weekly Trade News Digest (online ed, 21 November 2012).

75 See Ian F Fergusson and others The Trans-Pacific Partnership Negotiations and Issues for Congress (Congressional Research Service, 24 January 2013). 
Model BIT, NAFTA, and the ASEAN-Australia-New Zealand FTA, it may be safe to predict that there will likely be general agreement for a "balanced" approach in the investment chapter in the TPP agreement.

The early indications are that the TPP will include an investment chapter with substantive legal protections for investors and mandatory investor-State dispute resolution: in 2011, the negotiating States issued a statement confirming that the proposed TPP would include "expeditious, fair, and transparent investor-State dispute settlement subject to appropriate safeguards. "76

New Zealand is likely to face a choice: should it embrace the developing system of investment treaty arbitration or opt out of it? ${ }^{77}$ This is not a decision to be made lightly and it is likely to be difficult to reverse once made. There have been various attempts in New Zealand by pro- and antiTPP advocates to try to sway public opinion. ${ }^{78}$ Neither side appears (yet) to have been successful.

Williams and Kawharu summarise the position in their text: ${ }^{79}$

New Zealand's evolving position on investment treaty arbitration will depend partly on negotiating and political factors. It will also depend partly upon whether - as a matter of principle - New Zealand approaches investment treaty arbitration as a system which can be made useful and tolerably safe through appropriate and careful drafting; or as a system which, by its very nature, is more dangerous than it is beneficial. There is no doubt that the investment treaty regime is a developing global legal system. New Zealand is still determining what part it wishes to play in the development and refinement of that system.

\section{Precisely.}

\section{REFLECTIONS}

Like any system, investment treaty arbitration has strengths and weaknesses. We reflect on some of them and hopefully dispel some of the myths that have developed about this area of international law.

76 Office of the United States Trade Representative Enhancing Trade and Investment, Supporting Jobs and Economic Growth and Development: Outlines of the Trans-Pacific Partnership Agreement (12 November 2011).

77 One possible option if New Zealand does not want to take on the risk of investment treaty arbitration is to opt out in the way New Zealand and Australia did in the ASEAN-Australia-New Zealand FTA, above n 8.

78 Open Letter from Lawyers to the Negotiators of the [TPP] Urging the Rejection of Investor-State Dispute Settlement (8 May 2012) (available online at <http://tpplegal.wordpress.com/open-letter/>). See also Open Letter from various signatories to John Key (Prime Minister of New Zealand) in Support of the TPP negotiations (3 December 2012) (available online at <http://media.nzherald.co.nz/webcontent/document/ pdf/201249/tp2.pdf>).

79 David AR Williams and Amokura Kawharu Williams \& Kawharu on Arbitration (LexisNexis, Wellington, 2011) at 896 . 
First, investment decisions are typically complex and are rarely made on the basis of one factor alone. If a host State has a transparent court system, an independent judiciary and the rule of law, investors may be attracted by investment opportunities even though international arbitration is not on offer. Even without these attractions, an investor may decide to take its chances because the potential rewards outweigh the risks. Ultimately, these are commercial decisions.

In our experience, many investors see treaty protections as an added benefit that allows them to reduce some of the risk of their investment. Investors are becoming increasingly interested in structuring their investments to make sure they get the benefit of treaty protection. This means that commercial lawyers need to be aware of how their clients stand to benefit from treaty protections. Foreign investors looking to invest in New Zealand and New Zealand investors looking to invest overseas will expect advice on how to structure their investments to benefit from treaty-based investor protections. If the TPP goes forward, a European company may choose to invest in New Zealand through a subsidiary in the United States to obtain TPP investment protections. Similarly, a New Zealand company looking to invest in Latin America may incorporate a subsidiary in the Netherlands to gain access to its investment treaties with Latin American States.

Second, there is an arbitration risk. If you give foreign investors the right to sue you, there is a risk - even a likelihood - that they will seek to use it. But, as mentioned above, a balanced assessment needs to be undertaken. There is too much scaremongering in this area. A responsible and well-advised government should not be afraid of getting sued. There is no reason why a State cannot back itself to win, by making a persuasive case justifying its conduct. As Daniel Kalderimis has noted: ${ }^{80}$

The risks of investor-state arbitration should not be overstated. The United Kingdom, France, Germany, the United States and Australia have, for instance, never lost an investment case (though Germany did settle one claim). This is not surprising as investment treaties guarantee minimum rights, not flawless regulation.

This does place the onus on officials to advise the Government well on the international law implications of different policies. If they do that, any risk of an adverse arbitration award can be minimised. And ministers will expect to be warned in advance of the possibility that a policy initiative may infringe a foreign investor's legitimate "rights". ${ }^{81}$

80 Daniel Kalderimis "Investor-State Arbitration and the TPP: Should You Be Concerned?" (1 June 2012) AMINZ <www.aminz.org.nz>.

81 We note that as awareness of New Zealand's international trade and investment treaties increases, domestic lawyers may seek to challenge administrative decision-making before the New Zealand courts. The courts have held in the context of unincorporated human rights treaties that New Zealand's international obligations are mandatory relevant considerations to be taken into account in administrative decisionmaking (see Tavita v Minister of Immigration [1994] 2 NZLR 257 (CA)) and that discretionary powers must 
It is also crucial to look at the protections that are actually offered to investors: fair and equitable treatment - whether or not it is tied to the customary international law minimum standard; freedom from expropriation without full compensation; equal treatment with host State nationals; and equal treatment with investors from other States. These are not onerous standards. The specific exceptions in New Zealand's treaty protections maintain sufficient space to regulate in the public interest. In those circumstances, States like New Zealand should arguably be keeping these standards whether obliged by a treaty or not. If a State violates one of these standards, it does not seem controversial that it should pay compensation to make the investor whole.

Third, there is also sometimes criticism that private international tribunals are making decisions with potentially significant policy and financial implications for host States. But look at who is actually making these decisions. Arbitrators are typically senior lawyers with international law expertise, including law professors, leading barristers and retired members of the judiciary. The fact they are not from an investor's country or the host States is a strength of the system. New Zealand already makes a distinguished contribution to international investment arbitration. David Williams QC, Sir Kenneth Keith, Professor Campbell McLachlan QC and other New Zealanders sit as arbitrators in investor-State disputes. Many more represent investors and States before international tribunals. This should increase as investment treaty arbitration comes closer to home in New Zealand. It is no coincidence that the first comprehensive arbitration text in New Zealand, Williams \& Kawharu on Arbitration, was published in 2011 and devoted several chapters to investment treaty arbitration.

Fourth, investment treaty arbitration is a two-way street. We expect to see a reaction in Australia to the new policy particularly among mining companies. There are a number of reasons why the chief executive officer or general counsel of a New Zealand outbound investor might be reluctant to subject the company to Chinese, Indian or Russian court systems. It is also unrealistic to expect that the New Zealand Government would be quick to pressure the Chinese, Indian, or Russian Governments diplomatically. Investment treaty arbitration "allows the true complainant to face the true defendant". 82

Fifth, investment arbitration is an evolving system. The recent wave of cases has exposed the tension between an investor's international rights and the host State's ability to regulate. A detailed exploration of this tension and attempts to balance it is beyond the scope of this article. However, some brief comments may help illustrate the evolution of investment treaty law. Bearing in mind that the tribunal's ultimate task is to apply a particular treaty to a particular set of facts, the way in which other tribunals have resolved similar problems may assist the process. However, this

be interpreted and exercised consistently with those international obligations (see Attorney-General $v$ Zaoui \& Ors (No 2) [2005] NZSC 38, [2006] 1 NZLR 289 at [91]).

82 See Paulsson, above n 32, at 256. 
"jurisprudential" approach also exposes the normative ambiguity within the structure of investment treaty arbitration because the development of treaty-based investment protection has been ad hoc, decentralised and, until the recent trend toward broad FTAs with investment protection, largely bilateral. There has been little room for analysis of the possible investment treaty norms or the inherent risks of generalising beyond a particular treaty or transplanting doctrines from other parts of international law such as international trade or international human rights law into investment dispute resolution.

Facing State concerns about the tension between State regulation in the public interest and foreign investor rights, and criticism of arbitrators as unelected regulators, it is critical to recall that States control the treaty drafting process. Ultimately, States can undo obligations they have previously entered into if they so decide, albeit with delays. Like New Zealand, more States are likely to adopt a more "balanced" approach to drafting investment treaties in the future, drawing on the lessons of the past 20 years.

In the interim, counsel and arbitrators can consider (within reason) the interpretive resources existing within the international legal system. There is significant potential in what Professor McLachlan has called "the principle of systemic integration"83 - art 31(3)(c) of the Vienna Convention on the Law of Treaties ${ }^{84}$ - to harmonise different international norms through the process of interpretation. Article 31(3)(c) is an interpretive rule and does not compel any particular substantive result, but it nevertheless represents a useful tool for determining which norms investor protection, public interest regulation or, not infrequently, both - trump the others. Obviously, the determination of the relevance of an international norm turns on the particular facts and the text of the treaty at issue. If relevance can be established, art 31(3)(c) allows the investor protection standard to be interpreted consistently with the relevant principle of international law or treaty obligation. The presumption is that States intend to act consistently with general principles of international law when they enter into a treaty and do not intend to sign up to treaties that put them in breach of other international obligations. This type of interpretive approach pre-empts a conflict of norms.

Finally, providing for direct arbitration of foreign investment disputes embodies the rule of law at the international level. Remember the lessons of history: Venezuela may be one of the most sued States at ICSID today, but - unlike the turn of the 20th century - there are no foreign warships sitting in Venezuela's ports.

83 Campbell McLachlan "The Principle of Systemic Integration and Article 31(3)(c) of the Vienna Convention" (2005) 54 International and Comparative Law Quarterly 279.

84 Vienna Convention on the Law of Treaties, above $\mathrm{n} 23$. 


\section{CONCLUSION}

New Zealand is in an enviable position to decide for itself what use it wants to make of investment treaty arbitration. Unlike many States, New Zealand is unencumbered by old-style existing treaties, has the benefit of more than 220 investment treaty decisions, and the time to assess the rumours about this area of international law.

The choice ultimately boils down to a case-by-case balancing of New Zealand's inboundoutbound investment situation with the other contracting States and New Zealand's confidence in its ability to manage the risk. Yes, there is every chance that New Zealand will find itself sued before an international arbitration tribunal by an aggrieved investor under one of its FTAs in the future. But, no, there is no reason why New Zealand should not expect to prevail with careful treaty drafting and good regulation.

It is appropriate to finish with the cautionary note on which we started: investment treaty arbitration gives rise to both risk and opportunity. This is true of international economic relations generally. Tasman's expedition came to New Zealand all those years ago looking for precious metals, but they left New Zealand empty-handed after an ill-fated encounter with the indigenous population. Tasman called the scene of this encounter Murderers Bay. The irony of course is that gold - the very metal Tasman had been sent to find - was discovered there many years later by the British, who gave the bay its modern name: Golden Bay.

Whatever decision New Zealand makes about investment treaty arbitration, it is to be hoped that it will facilitate more profitable and enduring relationships than Tasman's expedition all those years ago. 
(2012) 43 VUWLR 